\title{
Social representations of sexual and reproductive rights: experiences of young men deprived of freedom'
}

\section{Representações sociais de jovens privados de liberdade acerca dos direitos sexuais e reprodutivos ${ }^{2}$}

\author{
Angélica Orozco-Idárraga ${ }^{a}$ \\ (D) https://orcid.org/0000-0001-9990-0532 \\ E-mail: aorozcol@unisimonbolivar.edu.co \\ Angela García-Navarro ${ }^{a}$ \\ (iD) https://orcid.org/0000-0002-6990-5110 \\ E-mail: agarciazळunisimonbolivar.edu.co \\ Jennifer Castillo-Bolaños ${ }^{a}$ \\ (D) https://orcid.org/0000-0001-9687-1457 \\ E-mail: jcastilloı2@unisimonbolivar.edu.co

\section{Helena Morales-Ortega ${ }^{a}$} \\ (D) https://orcid.org/0000-0003-2874-4776 \\ E-mail: emoralesळunisimonbolivar.edu.co

\section{Yomaira García-Acuña ${ }^{a}$} \\ (iD) https://orcid.org/0000-0003-0806-2145 \\ E-mail: ygarciaı®unisimonbolivar.edu.co \\ a Simón Bolivar University. School of Social and Legal Sciences. \\ Barranquilla, Atlántico, Colombia.
}

\section{Correspondence}

Angélica Orozco-Idárraga

Carrera 54 N 59-102, Simón Bolivar University, Faculty of Legal and Social Sciences. Barranquilla, Colombia Carrera 54 N859102Barranquilla, 57, Colombia.

\section{Abstract}

This paper aims to submit a research results whose objective is to interpret social representations considered by young inmate males from the Centro de Educaciòn El Oasis, in relation with sexual an reproductive rights and their incidence in adolescent pregnancy, in order to lead them to a resignification process evident in their own life project. It is a qualitative study developed from a participatory methodology in Colombia, 2015. The sample consisted of a total of 60 young adults, including 46 teens and managers. The techniques used were a social survey given to 46 adolescents, an unstructured interview to 30 , focus groups and resignification workshops. The representations by teenagers and young people about the subject came from female figures, inculcated early, when still in their homes, according to the socio-cultural contexts in which they were inserted. Thus, their beliefs do not favor the development of practices aimed at preventing diseases and teenage pregnancy, in addition to reinforcing stereotyped ideals of masculinity and femininity and prejudices in relation to sex, prioritizing sexist and homophobic notions regarding gender roles.

Keywords: Social Representations; Sexual Rights; Pregnancy in Teenagers; Paternity and New.

\footnotetext{
This article is a product of the research project entitled "Novel meaning of the social representations by young inmates of the Oasis Rehabilitation Center about sexual and reproductive rights and the prevention of pregnancy in teenagers." A gender-approached study on young men, through Contract No.312, Cooperation and association agreement between the Colombian Institute of Regional Family Welfare, Atlántico (ICBF) and Simón Bolívar University in 2015.

2 This article is a product of the research project entitled "Novel meaning of the social representations by young inmates of the Oasis Rehabilitation Center about sexual and reproductive rights and the prevention of pregnancy in teenagers." A gender-approached study on young men, through Contract No.312, Cooperation and association agreement between the Colombian Institute of Regional Family Welfare, Atlántico (ICBF) and Simón Bolívar University in 2015.
} 


\section{Resumo}

Este artigo apresenta os resultados de uma pesquisa cujo objetivo consistiu em interpretar as representações sociais de jovens detentos no Oasis Center acerca dos direitos sexuais e reprodutivos e a incidência destes em gravidez na adolescência, a fim de conduzi-los a um processo de ressignificação que permite o exercício responsável desses, evidenciada em seus projetos de vida. Esse é um estudo qualitativo desenvolvido a partir de uma metodologia participante, na Colômbia, em 2015. A amostra foi composta por um total de 60 jovens adultos, incluindo 46 adolescentes e gestores da instituição. Para a coleta de dados, foram utilizados grupos de foco, oficinas de resignação, uma pesquisa social aplicada a 46 adolescentes, e uma entrevista não-estruturada realizada com 30 adolescentes. As representações dos adolescentes e jovens acerca do assunto foram oriundas de figuras femininas, inculcadas ainda em suas residências, de acordo com os contextos socioculturais em que estavam inseridos. Dessa forma, suas crenças não favorecem o desenvolvimento de práticas voltadas à prevenção de doenças e gravidez na adolescência, além de reforçarem ideais estereotipados de masculinidade e feminilidade e preconceitos em relação ao sexo, priorizando noções sexistas e homofóbicas relativas aos papéis de gênero.

Palavras-chave: Representações Sociais; Direitos Sexuais; Gravidez na Adolescência; Paternidade e Novidade.

\section{Introduction}

The youth and teenagers face several problems concerning the employment of sexual and reproductive rights, including those related to sexually transmitted diseases (STDs), unwanted pregnancies, and maternal mortality at the time of pregnancy termination. Other issues involve cultural, political, and social factors; discriminatory and scarcely inclusive legislation that prevents the circulation and appropriation of information regarding their sexual and reproductive rights and the relevance that should be granted to gender equity; and early onset of sexual life (Betancourt, 2014).

According to the World Health Organization (WHO), in a study conducted by Jiménez-González, Granados-Cosme and Rosales-Flores (2017), teenage pregnancy statistics for 2013 in Mexico showed that between 15 and 19 years of age, 16 million girls were pregnant and that one million teenagers aged less than 15 years gave birth. Furthermore, three million girls between 15 and 19 years of age put their lives at risk by undergoing abortions every year. In this context, the birth rate among teenagers in Latin America and the Caribbean is $18 \%$, higher than that in high-income countries. This issue is worsened by the deficient attention of health systems and the public policy that permeates it.

Despite the efforts toward preventing adolescent pregnancy in Colombia, the Encuesta Nacional de Demografía y Salud (Colombian Demographic and Health Survey - ENDS) conducted by the Ministry of Health and Social Protection and Profamilia in 2015, reported a decline of 2.o points in 15-19-year-old fertility rates during the 2012-2015 period, which was 2.1 during the 2007-2017 period. The report points out that this issue leads to consequences such as school desertion, early pregnancies, and low levels of accessibility to sexual and reproductive health programs.

The Development Plan of the Atlántico Department (2016-2019) affirms the following:

The fertility rate among adolescent girls aged between 15 and 19 years has had an increase of 12.77 points from 2011 to $2013,5.68$ points above the national average (69.25). On the other hand, in girls aged between 10 and 19 years of age, the fertility 
rate has increased-for 2013, a rate of 38.51 was registered, which is 6.41 points more with respect to 2011 and 2.18 points above the national rate (36.34) (Gobernatión de Atlántico, 2016, p. 56).

All of these statistics show that teenage pregnancy has increased in the international, national, and local spheres as a result of a different family, social and economic conflicts. Moreover, it should not be forgotten that public policies focus more on attention than on prevention for the exercise of a healthy, safe, and responsible sexuality. Regarding this, social representations by people are important because they can exert some influence not only on the perception of the world but also on the actions of people. Concerning sexuality, Petrella (2008) states that it is an expression of the integration of values such as respect, consideration, love for oneself and others, beliefs, attitudes, activities, practices, functions, and relationships.

The concept of sexuality by Lagarde (2005) was used for this study with a gender perspective; Lagarde defines sexuality as follows: "It is a cultural complex determined throughout history, consisting of social relations, social and political institutions, as well as the conceptions of the world, which defines the basic identity of the subjects" (p. 184).

In this context, it is understood that sexuality is developed through the interaction between the individual and the social structures, and teenagers' families have the maximum influence on the construction of the foundations for the sexual behavior of teenagers. People that are in conflict with the law are also included within this context, such as adolescents and young people in the Oasis Rehabilitation Center that works for adolescent offenders, who are also the participants of this study. These are young people between the ages of 14 and 22, some of whom entered the Center as infants and have reached their legal age while in the Center. Generally, when a reference is made to adolescent pregnancy, it is related only to females, neglecting the importance of the father figure of young men. Therefore, new masculinities and their relationship with this problem were researched and the project proposed the following question: What are the social representations by the adolescents in the Oasis
Rehabilitation Center about sexual and reproductive rights and their relevance in teenage pregnancy?

Thus, this article presents the findings through five sections. The first section is the introduction; the second section summarizes the theoretical reference and specific objectives; section three relates the method; section four includes the results; and section five presents the conclusions.

\section{Social representations and sexual and reproductive rights}

The social representations in this research are mainly based on Moscovici (1986) and Jodelet (1986). They regard that the social representation of a subject (concerning the individual him- or herself, family, class, group, etc.) arises in accordance to another subject; in other words, it designates a form of social thought. This fact was identified by García et al. (2009) in a review, after analyzing studies on the identification of content. However, García et al. (2009) believe that such studies did not account for the phenomenon of sexual/reproductive rights, whereas other researches replace beliefs, perceptions, attitudes, etc.

As for the structure of social representation following Moscovici (1969 apud Banchs, 200o) divided it into information, field of representation, and attitudes. However, he proposed separation between the processes and contents of social thought, according to which the processes would have no variations, whereas the cultural contents remain determined, with the process being the manner of thought.

Jodelet (1986) identifies six approaches that provide a dimension to the context. First, the subject who is in a situation of social interaction and representation is approached through the concepts of social psychology, and the resignation of belonging refers to behavior. The second approach concerns the aspects of representative activity; the subject is the creator of meaning, which is represented in his/her representation. In the third approach, the representation is a form of speech; the subjects who speak and the purpose of what they speak are dealt with. The fourth approach concerns the social practice of the subject as the main player, with a position or place that reflects institutional 
standards. The fifth approach involves the dynamics of the representations that depend on intergroup relations. Finally, the sixth approach focuses on socializing, which turns the subject into a bearer of social determinations. In this perspective, the relations between the mechanisms of domination and social representations are considered.

Considering the population on which this study was conducted, it is stated that given the broad use of the concept of social representations, linking it with not only a form of social knowledge but also social practices was interesting. In the case under study, the concern was the awareness and exercise of sexual and reproductive rights and the experience of sexuality by young people. Thus, the concept guiding the research is the one presented by Jodelet (1986).

\section{Adolescence, sexual and reproductive rights, and teenage pregnancy}

Adolescence constitutes a stage of development of an individual and has its own characteristics; during this stage, an individual shows his/her desire to build and strengthen his/her own identity based on the recognition of his/her needs and interests. In this sense, the Attorney General's Office-UNICEF affirms the following:

Adolescence is a stage of human development with its own nature; it is a period where a child's identity is no longer enough and a new identity is built from the recognition of one's own needs and interests. The guarantee of the rights to health and education and the active participation of adolescents and young people constitutes a key element for the social, economic, and political progress of a country. (2005, p. 52)

This is in line with the Colombian Code for Children and Adolescents (COLOMBIA, 2006) that establishes in Article 3 that adolescents are defined as people between 12 and 18 years of age. In the same way, in UNICEF's State of the World's Children Report (UNICEF, 2011), adolescence is understood as the stage that offers opportunities for children and adolescents but also demands a commitment to their life projects during this stage of their lives.
The purpose is to guide them and provide them with the tools that allow them to face risk factors and vulnerable states; in this way, their human and integral development is guaranteed.

Among the problems faced by adolescents and young people concerning their sexual and reproductive health, teenage pregnancy is one of the most significant; in the 1960 s and 70s, it became a social concern, resulting from the loss of values in families and the disintegration of social and community relations Jiménez et al. (2004). By the end of the 1980s, a study entitled "Risking the Future" conducted in the United States concluded that adolescent motherhood becomes the worst event that can occur in a woman's life because it blocks all her educational, professional, and effective opportunities to which she would have access had she not been a mother at an early age. Concerning the labor market, being an adolescent mother represents lower labor participation and lower remuneration (Hofferth et al., 1987, apud Martes, 2010).

To delve deeper into the issue, some figures that reveal its magnitude are presented. According to the United Nations Fund for Population (UNFPA) (2013) and UNICEF (2013), "Every day, 20,00o women under the age of 18 give birth in developing countries and 2 of the 7.3 million adolescent births that occur each year correspond to girls under 15 years of age" (page 8). For 2012, in Colombia, the guidelines for the development of a strategy for the prevention of pregnancy among adolescents and the promotion of life projects for children, adolescents, and young people between the ages of 6 to 19 were outlined through the National Economic and Social Policy Council (CONPES) 147 (COLOMBIA, 2012). The strategy is based on constitutional principles, Law 1098 of 2006 or the Law on Childhood and Adolescence, and on the implementation of sexual and reproductive rights (SRRs); it guarantees the protection and restitution of the rights of children and adolescents (COLOMBIA, 2006).

We return to the proposals made by Fernández Moreno (200o), who pointed out that General System of Social Security in Health (SGSSS) operates disjointed since it is based on financial principles where the predominant is cost-benefit. Faced with the country's inequalities due to class, age, and sex, the possibilities 
of exercising sexual and reproductive rights were questioned, and he stressed the need for further studies on masculinities. It should be noted that in order to face this issue in Colombia, the Ministry of Health and Social Protection reviews and updates the National Policy on Sexuality, Sexual Rights and Reproductive Rights (PNSDSDR) since it was first outlined 10 years ago and is still in execution with a projection of years 2014-2021. This policy aims to overcome the medical perspective with which sexuality has been approached by linking rights, gender, and a differential focus.

As a projection for the year 2021, all Colombians are expected to recognize and assume SRRs as a human right, allowing them to experience a conscious, free, autonomous, and responsible sexuality (Profamilia, 2014).

These facts show the need to create more work aimed at adolescents and young men because they are not aware of the importance of dealing with responsible fatherhood as the role of motherhood has been historically and culturally assigned greater value and responsibility, downplaying the role of parenthood.

\section{Legal framework of SRRs}

Concerning SRRs, it is pointed out that these are principles that allow individuals to recognize, respect, and protect the political, cultural, racial, and sexual particularities of people; they are based on human dignity. These rights include the ability of women and men to autonomously and responsibly express and enjoy their sexuality without any risk of acquiring STDs, unwanted pregnancies, coercion, violence, and discrimination. Profamilia (2007) in Morales et al. (2017).

In the legal framework, the existence of a policy on sexual and reproductive health in the Ministry of Social Protection for the years 2002-2006 responds to the commitments made by Colombia in the $4^{\text {th }}$ International Conference on Population and Development held in Cairo in 1994 (although reference was already made to this subject at the Bucharest Conference in 1974), in the Fourth World Conference on Women in Beijing, and in the recommendations of WHO in a study by Morales et al. (2017).

In Colombia, the Constitution of 1991 (COLOMBIA, 1991), in its Article 2, emphasizes the guarantee of rights and duties as one of the essential purposes of the State, keeping SRRs within the framework of Fundamental Rights and of Social, Economic, and Cultural Rights.

Along these lines, the legislation on children and adolescents, concerning the issue of SRRs, is grouped under the principle of Integral Protection, which is acknowledged in the following: the Colombian Constitution; the Code for children and Adolescents; Law 1146 of 2007 on the prevention of and attention to violence and sexual abuse against children and adolescents; Law 1257 of 2008 (COLOMBIA, 2008) concerning the awareness, prevention, and sanction of forms of violence and discrimination against women; and the Decree 2968 of 2010 that creates the National Inter-sector Commission for the promotion and guarantee of SRRs. The purpose of this acknowledgment is to harmonize policies aimed at formulating and implementing the necessary programs and actions.

As significant advances, the Ministry of Social Protection, the Ministry of National Education (Colombia), and the Colombian Institute of Family Welfare promote strategies for coordination, coverage of services for adolescents and young people through health-friendly services, education on sexuality, and the construction of citizenship, and peacebuilding networks and SRRs for adolescents and young people.

\section{Method}

The research was conducted from a qualitative approach using participatory research methodology, which allowed us (1) to interpret and promote novel meaning processes of social representations of adolescents and young people about SRRs and teenage pregnancy and (2) to influence their life projects by raising their awareness about the implications and results of early pregnancy and the transmission of diseases when engaging in non-responsible sexuality. The scope of the research was descriptive because it sought to "specify the properties, characteristics, and profiles of people groups, processes, objects or any other phenomenon that is subject to analysis" (Sampieri et al., 2014, p. 92). 
The population consisted of 6o young people under the Criminal Responsibility System for Adolescents in Colombia, aged between 14 and 22 years. The sample was intentional and comprised 46 adolescents and directors of the Institution to whom the instruments designed and validated by experts were applied to the pilot test being endorsed by the Colombian Family Welfare Institute (ICBF). The techniques of gathering information were the social survey that was applied to 46 adolescents and young people for the characterization of these techniques along with a structured interview conducted with 30 young people and adolescents, including those who were parents. These techniques also included focus groups and workshops for providing new meaning to social representations, aiming at the entire population addressing demographic, socioeconomic aspects, family, personal relationships, and occupation of freetime. Unstructured interviews investigated three categories: awareness about sexual and reproductive rights, beliefs and myths about sexuality and sexual and reproductive health, and the exercise of sexual and the reproductive rights; Focus groups who make possible to deepen in relation to human rights warranty and vulnerability where the focus groups that delved into perceptions about human rights guarantee and violation of rights; as well workshops for consultation of the subject and resignification in the entire population.

The research was developed in three phases; the first phase researched inter-institutional coordination that involved the presentation of the present project, the invitation, review, and approval of the same by the ICBF, the signature of the Inter-institutional Agreement, and the beginning of the project. The second phase comprised the collection of primary and secondary information using the techniques and instruments stated in the project. In the third phase, workshops were conducted to provide new meaning to the social representations that adolescents and young people have regarding SRRs and regarding how they influence their life projects. This phase included four workshops on topics about different perspectives of masculinity; adolescence, SRRs, and teenage pregnancy; family planning methods; and sex and gender. The research team was comprised of 5 women professionals and two young researchers, with experience in teaching and research in subjects such as Social Work, Psychology, and Attorney, who established a dialogical relationship, empathy, and active listening with adolescents and young people.

For data analysis, the information collected by the social survey applied to 46 adolescents and young people was classified into categories, they are: demographic (age, origin, displacement due to violence, marital status); socio-economic (occupation, income, education level of both the young person and his family); family and personal relationships (family situation, character of family relationships, head of the family, people who lived with the young person before entering the Center, acts of domestic violence at home) and management of free-time. This categories were analyzed using SPSS software, which facilitated characterization.

The analysis of the results of unstructured interviews carried out with 30 adolescents and young people, including those who were parents, focus groups, and workshops was carried out in three stages: ordering and classification of the information; production of empirical concepts from descriptive analysis, and elaboration of theoretical concepts based on interpretation. The first one was done through transcripts of recordings of individual documents by interview, focus group and workshop held; elaboration of matrixes from the previous categories, supported by the $\mathrm{N}$ Live software for the handling of qualitative data, which facilitated the realization of the second one that consisted in the production of conclusions; and the third one consisted in the elaboration of theoretical concepts based on the interpretation of the discussion. From this perspective, the interpretation facilitated the integration of the qualitative findings with the theory of social representations.

\section{Results and discussion}

The main findings that emerged from the application of the techniques in relation to the objectives of the study are presented below. 


\section{Social Representations by Adolescents and Young people in the Oasis Rehabilitation Center}

This research aims to conduct a research about young people from Oasis Rehabilitation Center regarding to SRRs and teenage pregnancy, in order to promote a new meaning of these social representations. To define the individuals' awareness about these rights, their opinions and information about these rights and the sources from where they obtained those opinions and information were explored. Furthermore, the beliefs, myths, and meanings related to these rights and their practices were also researched; this also allowed the establishment of some perceptions about the exercise of their SRRs. As follows we submit main results based on the techniques suggested considered for the objectives of this research.

\section{Awareness about SRRs}

Concerning their awareness about SRRs and the prevention of pregnancy and STDs, most adolescents and young people referred to the concept of protection in two senses-first, to avoid pregnancy, and second, to fight against STDs. Other types of responses are related to their awareness regarding their body, specifically the male and female reproductive systems.

Information regarding SRRs has been acquired by young people from their families, mainly their mothers, grandmothers, aunts, and professionals at the Center; few of them acquired such information from educational institutions although most of these individuals were out of school before entering the Center, as evidenced by the survey $-76.1 \%$ were not studying and $23.9 \%$ attended an educational center $(n=46)$. However, those who were studying also said that they had received little information from the school.

They were interested in learning about STDs and their prevention, prevention mechanisms against pregnancy, and the fertilization process. An aspect that attracted attention during the workshops is the marked concern with the prostate and possible diseases related to it and the management of emotional aspects in the context of couple relationships.
In interviews and workshops, it was identified that young people perceive women as sexual objects. They acknowledge that they have lacked guidance regarding their SRRs, and thus, it seems important to receive information about the subject. Furthermore, they mentioned that "it is good to learn something new" and they would learn "in order to prevent STDs." In this sense, they consider that one way to prevent STDs is by having proper information about the person from the opposite sex and through a stable relationship. Being with women whom they know since childhood and the use of condoms was identified as a safe method of protection; one of the participants mentioned that "With my woman, I do not wear a condom, but with a different one, I do."

Concerning the prevention of pregnancy, the primary reason mentioned by many interviewees was the lack of awareness regarding family planning methods. It is evident that they have some information about these methods but little appropriation about their use is observed. In addition, beliefs about infertility persist in the face of injection, which causes them concerns about not being parents. Concerning the awareness and protection against diseases and the prevention againstpregnancy, categories related to gender and religious beliefs prevail and play a significant role; thus, they affirmed that "Well, when you need it, God sends you children". In context of the Colombian Caribbean, it is normal for men to demonstrate their virility by commenting on their peers about sexual relations with women, and if they are older, the act constitutes a greater feat. However, this can sometimes be questioned, but when a young man shows that has impregnated a girl, in general, no one will doubt his manhood. This corresponds to Fuller's (200o) considerations on the subject when he says "fatherhood has a natural, domestic, public and transcendental dimension" (p. 46). The capacity of men to impregnate a woman is the maximum demonstration of his manhood, which implies that fatherhood becomes the public demonstration of that control that he has over the body and sexuality of the woman he fertilizes.

Faced with the exercise of SRRs, among the most significant findings is the beginning of their sexual relationships. In this sense, the participants reported 
having relationships mostly with older women; for example, 10 years old boys would involve in a relationship with 12 years old girls, and 15 years old boys would involve in a relationship with 29 years old women. On the other hand, their answers showed that for them, sexual experience, preferably with older women, is a game and an opportunity to explore. They also experienced pressure from their peers who were older. Moreover, they are afraid of (1) being "run down" by the women who made advances at them and with whom they did not want to have sex and (2) being mocked by friends and lose leadership in the group. Some of the expressions that account for this pressure are "When I was younger, as I always walked with older guys than me, I first had sex at the age of 10, then at 11, and then I did it from time to time. My friends walked with leitas [prostitutes] on the corner and I alone. Eventually, we all went with leitas, coyote, and paiwa [sic], that is to say, an easy girl".

Another aspect that drew attention to the research group is that some individuals acted under family pressure to such an extent that some came to have the first sexual relationship with their mothers and other family members. The above corresponds to research by Holguín Mendoza and Esquivel (2013), who indicated that it is men who initiate sexual intercourse at an earlier age. In the workshops and focus groups, the youth stated that they have sometimes had sexual relations for fear of being "bullied", that is, the object of ridicule and malicious comments by women who have initiated a seductive action that he declined, not wanting to have sexual intercourse.

When inquiring about the representations of these young people about sexual orientation towards people of the same sex, their faces and responses reflected rejection and intolerance with this population group, some even stated that they had attacked them psychologically and physically. This reaffirms the consideration of the role of homophobia as one of the pillars of patriarchal culture. At the same time, young people lean on the Bible to affirm that God created only man and woman; other genders were not created by God. However, their response was totally contrary concerning sexual relations between women; such relations were more acceptable to them, and in fact, they mentioned having lesbian friends-"I do have friends who are lesbians, I talk to them and they tell me their things, but I do not like homosexuality among men."

When consulting about the concept of SRRs, a lack of awareness was found; they related it to the denial of the Center to a "conjugal visit," especially for those who had a stable relationship and for those with children. Within the framework of these relationships, they believe that they vulnerate and violate this right. They argued that the Institution has sufficient spaces that can be prepared for this purpose; however, they are aware that as they are infant, they are not allowed to be visited by their spouses and they define it as a "struggle they have to endure." They highlighted that awareness and information received in the framework of the project on SRRs are of great importance because it will help them generate greater awareness regarding decision-making and the implementation of those rights in their lives. The analysis of representations from a more recent perspective, linked to discursive approaches, allows us to see how young people challenge the instituted order and show critical positions towards institutions.

\section{Beliefs and myths about sexuality and sexual and reproductive health}

In line with this, representations, such as men having more women are more "macho", are predominant. However, in their speeches, they claimed to have an official girlfriend, the steady one with whom they said they were as serious because "they officially took those girls out of their house"; however, they also had "bad friends," referring to eventual relationships, without any commitments, known as "foolarounds." With such women, they had fun and consumed psychoactive substances. These representations showed the prejudices and stereotypes from the perspective of gender, concerning sexuality, in the sense of differentiating between women to be taken in a serious relationship and women to be taken only to have fun and satisfy their sexual desires when they feel alone. This is confirmed in their speeches, such as the following: 
"I've had more than one girlfriend at a time; I had two girlfriends-the "foolaround" and the "permanent one." When I want to go out with another woman, the permanent one is going to stay home, even knowing what I am doing... " these young people validate promiscuity as normal and acceptable behavior for men and it is a reason for moral and social criticism in the case of women. These gender differences in the sexuality of young people have also been found in other studies at the national level (Rodríguez; Vélez, 2009), which have indicated that both feminine and masculine identity are historical constructions, based on the sexual division of labor and on the patriarchal system that supports gender inequality. On the other hand, in Latin America, the crisis of masculinity has emerged in a context of the transformation of values and changes, product of industrialization, urbanization that transform the traditional sexist and patriarchal society (Castillo; Morales, 2013).

In line with the findings, only two young people expressed interest in being alone with their partner because they believe that being with several women is a sexist practice and is done by selfless men who follow their father figures and peers as examples. This has a significant influence because a father is the most important male figure for the development and formation of the attitudes and representations of young people in the face of conceptions of masculinity and in their ways of relating to and living with their sexuality. According to the latter, the participating population is permeated with traditional cultural patterns of masculine and feminine identities.

Concerning the use of condoms, the belief about the decrease in sexual satisfaction when condoms are used was found. They also consider condoms unnecessary when having stable relationships or a "steady" girlfriend, and mention that by using condoms, they did not establish a real connection with females. This is consistent with the findings of Peralta and Campuzano (2007) that affirmed that the use of condoms is conditioned by the type of couple and the relationship they establish.

Most of the participants who got pregnant, accepted the responsibility they have in family planning and birth control; They also, associate women's responsibility with the their historic assigned roles of reproduction and care of their children, that is why they must decide and handle these issues; they also deny that men have an active and leading role in this process. It is worth mentioning that most family planning programs are aimed at women and are reflected in the few programs on family planning directed at men, which in turn do not have a comprehensive perspective. This is stated by UNFPA (2007) when they mention that health services aimed at young men are often limited to the distribution of condoms or the testing and treatment of STDs.

The beliefs and myths around lyrics of songs and musical rhythms also have a great cultural value for this population because such myths and beliefs are built around them in cultural elements that facilitate conquering the opposite sex through dancing. Among the predominant musical genres, champeta and reggaeton were mentioned because they consider uninhibited rhythms that facilitate conquering. In the same way, they affirmed that dancing to these rhythms while consuming alcoholic beverages or drugs incites them to have sexual relations; it provokes or stimulates the desire of both the male and the female, which is considered positive for them. One of the participants mentioned the following: "I made her dance and she fell in love with me; it was like a reggaeton; I told her 'I want to be your boyfriend, do you accept me?' and she said yes. So, today before you leave, I'm going to give you a kiss to see if this is true". The above matches the studies by Penagos (2012) and UNFPA (2007) on the power of music such as reggaeton and its influence on the lifestyle of young people. Some recognize that certain genre lyrics such as reggaeton have negative influences on women because they are sexist but still like to dance on it due to the rhythm.

\section{Paternity and new subjectivities}

Regarding paternity, it is emphasized that these adolescents and young people claim their roles and responsibilities as parents despite having an unplanned pregnancy. It is worth mentioning that the report by UNFPA (2013) indicates that for adolescents and young people aged under 
18 years-old, and in particular those aged under 15 years-old, pregnancy for women and paternity concerning men is not a result of a consensual decision. On the contrary, both pregnancy and paternity were claimed to be the results of the absence of decision-making power and of circumstances beyond the control of adolescents and young people. These circumstances are related to the impairment of decision-making powers, poverty, pressure from friends, peers, and family and communities; importantly, in most cases, early motherhood and paternity are the result of violence and sexual coercion.

In line with the above, the results showed that pregnancy was unplanned and came as a surprise and that the children were conceived under the effects of drugs in some cases. Only one of the interviewees said that he wanted to have children. However, most consider their paternity and the fact of having a child in adolescence as a blessing. Among the statements, the following is highlighted: "[The baby] was not planned. I did not know that she was pregnant. I realized with time that her belly looked bigger. I asked her, 'What, are you fat?' She replied, 'No... I'm pregnant for four months'. I said 'I told you on my [psychedelic] trip that you can't get pregnant'. I still do not want to have children. But I had sex with her and I got her pregnant because I wanted to have [children] when I became 18. But what are you gonna do? I had it at 15, but that was a blessing".

It is important to note that a new category emerged-the stepfather figure. Adolescents and young people who were parents were initially consulted, and before that, the researchers were asked to also consider their roles as stepparents. Here, we should remember that most of the participants had relationships with women older than them, who had also started their sexual lives at early age. They took on their partners and stepchildren as their properties and believed that they in turn should identify them as the father and authority in the family.

Some young people were worried about being parents and gained awareness regarding the deprivation of freedom by being parents; the activities of this project have made them see the consequences of their actions and have given them opportunities to think, analyze, and reflect. One of the respondents mentioned, "You know, one does not think; here [in prison] is where one thinks." Due to the conditions of insecurity that surround these young people in conflict with the law, they face paternity as a synonym of hope and prolongation of their existence if they die at an early age as a result of their lifestyle. The scenarios in which the paternity of adolescents and young people interviewed in this study take place are characterized by the consumption of psychoactive substances, alcohol, connection to gangs, crime, fleeing their homes, unemployment, adolescents being expelled from their home when they get pregnant, etc. This forces them to begin a young family, drop out of school, or abandon their work.

In this sense, teenage pregnancy becomes a violation of human rights due to the consequences and effects for both women and men. This translates into dropping out from school, leading to responsibilities and commitments for which they are not prepared and denial of their right to education. Moreover, young people who do not have access to information on pregnancy prevention and contraceptive methods are denied the right to health (UNFPA, 2013).

Herein, the protection of adolescents and young people from phenomena that, like early pregnancy, limits their integral development and can be eradicated from a gender-focused education, in which the meaning of being men and women today, transforming positive and loving masculinities are formed capable of recognizing diversity (Vela; Yes, 2014).

\section{Conclusions}

This study concludes that young people have little or no awareness regarding SRRs; bodies of men and women and the functioning of their reproductive organs because they in general related both to the sexual acts; and pregnancy and relationships although very few got anywhere near understanding sexuality as a right. They also showed great concern in the workshops on prostate diseases and have the representation that having sex at an early age and inadequate practices can lead to weak conditions since adolescence.

In the process of renewing the meaning of social representations through the workshops, 
the participants were able to identify that SRRs are a part of human rights. They also mentioned some beliefs and myths on topics such as family planning and STDs. Evidently, most of the young people had little awareness about these topics and those who reported knowing them had acquired them through family and friends in an inappropriate way. Thus, they identify being with women they have known for a long time as a safe way of protection. Therefore, the workshops for new meanings to social representations allowed clear and scientific information for the participants regarding the methods of family planning, STDs, and pregnancy prevention, working on the myths and beliefs around these issues.

For most of them, pregnancy was unplanned, and children were conceived under the effects of drugs; this validated their experience as an extension of their existence in case of early death due to the risk factors that affect their integrity and their life projects.

Exploring the perceptions among young people regarding masculinity and femininity was possible and allowed to establish that most of them had many stereotypes and prejudices about gender and that they prioritized conceptions related to traditional roles, prejudices around identity, expression, and sexual orientation. These conceptions obey the male heteronormativity that constitutes the identity of these young people for having been socialized from the patriarchal model. The heteronormativity, for being a power regulator, indicates who are subjects within the political sphere, Butler (2007), which is consistent with the definition by López (2017) "heteronormativity is the political, social, philosophical and economic regime that generates violence towards all those people who do not follow a pattern of gender, sexuality, practices, and desires associated with heterosexuality" (p. 228). From this concept, it is understandable that most of them mentioned that they did not agree with same-sex relationships and their answers showed intolerance toward any sexual orientation apart from heterosexuality. However, from the gender identity, it is maintained that sexual behavior goes beyond the binary division between man and woman, because "the political struggle for the vindication of other gender identities has thus extended to other sectors, which they seek the recognition of a very wide diversity of identities that have also been historically rejected" (Leivi, 2014, p. 327). The new meaning given to their representations was achieved concerning the role of women as well as men, and they regarded the representations in terms of equality from the social dimension. They identified that the only thing that differentiates men and women is their sexual organs. This was of great importance because it questioned some of their prejudices and stereotypes around sexuality and also allowed them to view each situation from a different perspective with people who have different ideas and conditions. Herein, it is recognized that the study did not cover queer, trans, intersex, and other ways of assuming sexuality. In the workshops and focus groups, the rejection towards homosexuality was also evidenced, which is why heterosexuality/ heteronormativity is present in the speeches of young people and their invisibility reproduce prejudiced practices based on gender (Sánchez, 2019).

It is important to consider that the ignorance and lack of interest by men in issues related to family planning are related to the influence of sociocultural traditions that have marked the conceptions of masculinity. This goes beyond and must be considered from a gender perspective, from new masculinities, and the law. Without ignoring that this articulation is not exempt from tensions as pointed out in their reports from both the academy and activism Fabbri (2016) and Fernández Moreno (2016).

We acknowledge the efforts by the ICBF and point out the institutional offer to work within the Adolescent Criminal Responsibility System (SRPA). It's important not to fail to mention the shortcomings in addressing youth problems, the low budget, and the privatization of health services, where the market is the one that dominates. At the same time, other risks and opportunities arise for the adolescent and young population, whose analysis goes beyond the work carried out in the framework of this project.

\section{References}

BANCHS, M. A. Procedural and structural approaches to the study of social representations. Papers on social representations, Lisboa, v. 9, p. 3.3-3.15, 2000. 
BETANCOURT, H. (Coord). Training Guide on Adolescence and Youth, Sexuality and Sexual and Reproductive Health. In: Confederation of Adolescents and Youth of Ibero-America and the Caribbean. Salvador. Disponível em: <http://www. codajic.org/sites/www.codajic.org/files/Manual\%20 PDDH\%2oUNFPA\%2OSSR\%E2\%80\%9CPara\%20 Talleres\%2ode\%2oCapacitaci\%C3\%B3n\%20 sobre\%2oAdolescencia\%2oy_o_o.pdf >. Acesso em: 12 jul. 2021.

BUTLER, J. El género en disputa: el feminismo y la subversión de la identidad. Barcelona: Paidós Ibérica, 2007.

CASTILLO, J.; MORALES, H. Los estudios de género a las nuevas masculinidades y/o los movimientos de padres por la custodia compartida de sus hijos e hijas. Educación y Humanismo, Barranquilla, v. 15 n. 24, p. 107-121, 2013.

COLOMBIA. Constitución (1991). Constitución Política de La República De Colombia. Bogotá, DC: 1991.

COLOMBIA. Ministerio de la Protección Social. Ley 1098 de 2006. Bogotá, DC: 2006.

COLOMBIA. Ministerio de Educación Nacional. Ley 1146 de 2007. Bogotá, DC: 2007.

COLOMBIA. Ley 1257 de 20o8. Bogotá, DC: 2008. COLOMBIA. Documento Conpes Social $N^{o}$ 147/2012: Lineamientos para el desarrollo de una estrategia para la prevención del embarazo en la adolescencia y la promoción de proyectos de vida para los niños, niñas, adolescentes y jóvenes en edades entre 6 y 19 años. Bogotá, DC: 2012.

COLOMBIA, Decreto 2968 DE 2010: Comisión Nacional Intersectorial para la Promoción y Garantía de los Derechos Sexuales

y Reproductivos. Bogotá, DC: 2010. Disponível em: <https://www.icbf.gov.co/cargues/avance/docs/ decreto_2968_2010.htm>. Acesso em: 12 jul. 2021.

FABBRI, A. Colectivos de hombres y feminismos: aportes, tensiones y desafíos desde (y para) la praxis. Revista Sexualidad, Salud y Sociedad, Río de Janeiro, n. 22. p. 355-368, 2016. DOI: 10.159o/1984-6487.sess.2016.22.16.a
FERNÁNDEZ MORENO, S. Y. La masculinidad en el área de la salud sexual y reproductiva: Un campo por descubrir. In: Memorias del foro masculinidades en Colombia. Reflexiones y perspectivas. Bogotá, DC: AVSC International y Fondo de Población de las Naciones Unidas, 200o. p. 37-52. Disponível em: <https://pesquisa. bvsalud.org/portal/resource/pt/lil-276058>. Acesso em: 12 jul. 2021.

FERNÁNDEZ MORENO S. Y. Varones y en clave feminista: trascendiendo invisibilidades, ausencias y omisiones. Revista Sexualidad, Salud y Sociedad, Río de Janeiro, n. 22 p. 249-277, 2016. DOI: 10.1590/1984-6487.sess.2016.22.11.a

FULLER, N. Significados y prácticas de paternidad entre varones urbanos en el Perú. In: Paternidades en América Latina. Lima: Pontificia Universidad Católica del Perú, 200o. p. 35-90.

GARCÍA, Y. et al. Social representations: theoretical aspects and research results. Barranquilla: Ediciones Universidad Simón Bolívar, 2009.

GOBERNATIÓN DEL ATLÁNTICO. Plan de desarrollo 2016-2019: Atlántico líder. Barranquilla: Departamento del Atlántico, 2016.

HOLGUÍN, M.; MENDOZA, L. A; ESQUIVEL, C. M. et al. Factors associated with the onset of sexual activity in adolescents from Tuluá, Colombia. Chilean Journal of Obstetrics and Gynecology, Santiago, v. 78, n. 3, p. 209-219, 2013. DOI: $10.4067 /$ So 717-75262013000300007

JIMÉNEZ, E. et al. Communication, participation and sexual and reproductive health in adolescents methodological reflections from the perspective of communication for social change. Research and Development, [S.I.], v. 12, p. 78-107, 2004.

JIMÉNEZ-GONZÁLEZ, A.; GRANADOS-COSME, J. A.; ROSALES-FLORES, R. A. Pregnancy in adolescents from a high-marginality rural community: a mixed case study. Public Health of Mexico, Cuernavaca, v. 59, n. 1, p. 11-18, 2017. DOI: 10.21149/8410

JODELET, D. Social representation: phenomena, concept and theory. In: MOSCOVICI, Serge (Comp.). Social psychology II: thinking and social 
life - social psychology and social problems. Barcelona: Editions Paidós, 1986. p. 478-494.

LAGARDE, M. The captivity of women: mothers, mother-wives, nuns, whores, prisoners and mad. Mexico City: National Autonomous University of Mexico, 2005. p. 184.

LEIVI, B. M. Identidad de género y diferencia sexual. Psicoanálisis, Buenos Aires, v. 36.n. 2, p. 303-332, 2014.

LÓPEZ, S. M. A. "Heteronormatividad". In: ARJONILLA E. O.; VILLENA, M. R.; MÉNDEZ, R. L. P. (Coord.). Barbarismos “queer” y otras esdrújulas". Barcelona: Bellaterra, 2017. p. 228-238.

MARTES, P. Determinants of the adolescent fertility rate in the department of Atlántico. Barranquilla: Institute of Economic Studies of the Caribbean, 2010.

MORALES, H. et al. Social representations of sexual and reproductive rights in adolescents and young people. Baranquilla: Simón Bolívar University, 2017.

MOSCOVICI, S. Thinking and social life, social psychology and social problems (social psychology). Barcelona: Paidós, 1986. v. 2.

PENAGOS, Y. Lenguajes del poder. la música reggaetón y su influencia en el estilo de vida de los estudiantes. Plumilla Educativa, Manizales, v. 10, n. 2, p. 290-305, 2012.

PERALTA, C. E.; CAMPUZANO, M. D. L. R. Relationship of condom use with dispositional and mediational factors in adolescents. Psychology and Health, Thousand Oaks v. 17, n. 2, p. 179-189.

PETRELLA, R. The sexual within sexuality in early adolescence. Valencia: University of Carabobo, 2008.

PROFAMILIA. Annual report of activities. Bogotá, DC: 2014.

PROFAMILIA. National Survey of Demography and Health. Bogotá, DC: 2015.

RODRÍGUEZ, A. F. U.; VÉLEZ, T. V. Susceptibility and self-efficacy against HIV/AIDS in adolescents from Cali-Colombia. Latin American Journal of
Social Sciences, Children and Youth, Manizales, v. 7, n. 2, p. 1513-1533, 2009.

SÁNCHEZ, J. J. M. La carta robada: un estudio sobre la (no)percepción de la heteronormatividad en el ámbito educativo. Discurso y sociedad, Logroño, v. 13, n. 4, p. 556-574, 2019.

SAMPIERI, R. et al. Methodology of research. Mexico City: McGranwHill, 2014.

UNFPA - UNITED NATIONS POPULATION FUND. Young men and HIV prevention: a toolkit for action. New York: 2007.

UNFPA - UNITED NATIONS POPULATION FUND. Maternity in childhood: facing the challenge of adolescent motherhood. New York: 2013.

UNICEF - UNITED NATIONS CHILDREN'S

FUND. Children, adolescents and the healthy environment in the departmental and municipal development plans. Bogotá, DC: La Imprenta Editores, 2005.

UNICEF - UNITED NATIONS CHILDREN'S FUND. Stateate of the world's childhood. New York: 2011.

UNICEF - UNITED NATIONS CHILDREN'S FUND. Strategy for the prevention of pregnancy in adolescence and the promotion of life projects for children, adolescents and young people between the ages of 6 and 19. New York: 2013.

VELA, L. A.; YES, B. V. Educación hacia las nuevas masculinidades:una propuesta de prevención del embarazo adolescente. Cultura de Guatemala, Ciudad de Guatemala, v. 2, p. 79-98, 2014.

\section{Authors' contribution}

Orozco-Idárraga y Garcia-Navarro are the responsable ones of conducting this research, data análisis and lead author of this paper. Morales-Ortega, Castillo-Bolaños y García-Acuña are the responsable ones of conducting this study and also were the ones who give the relevant conclusions.

Submitted date: 07/01/2020

Revised date: $07 / 01 / 2020$

Accepted date: 05/11/2021 